\title{
Methodology of the evolutionary economics in application to the engineering problems
}

\author{
E.B. Kolbachev ${ }^{1, *}$ \\ ${ }^{1}$ Platov South-Russian State Polytechnic University (NPI), Novocherkassk, Russia
}

\begin{abstract}
Authors present an idea that the consulting engineering services are a type of knowledge mediation institution. This institution decreases a possibility of the participants' opportunistic behaviour during the purchase and sale deal making. It's actual, first of all, for the knowledge products, such as innovation projects and R\&D results, and other search goods. In the article authors present a set of measurement instruments to make a said kind of valuation. Concept of the set is based on one of the evolutionary economics' methodologies: a technological structure method. As a criteria for attributing a project to one or another technological structure are used a level of the real technology's compliance with the extremely efficient, information materialization level, dimension scale of the forming processes and dominant management concept. The approach gives a possibility to minimize the possibility of the existence of the innovation processes participants' opportunistic behaviour, and to increase the efficiency of the innovation activities.
\end{abstract}

\section{Introduction}

New industrialization processes of the nowadays may be caused by different reasons in different countries of the world [1]. For example, authors of the well-known report [2] insist that the reasons for development of these processes in the USA are the following: unit labor costs are among the lowest in the industrialized world; energy costs are low thanks to the gas bonanza; the cost of capital is very low given the Fed's ultra-accommodative monetary policy.

The basic reason for the development of new industrialization processes in Russia is a consistent governmental policy of the last years. This policy is a result of understanding both by the government and the society how important the increasing of the country's human capital is for its economic development. The said task becomes vitally important because of a great harm to country's social capital in the beginning of the postSoviet period due to the destructive Yeltsin-Gaidar government policy and resulted in the elimination of many science intensive sectors of Russian economy [3].

Development of the new industrialization processes result in the stirring up the market of knowledge products, such as innovation projects, $R \& D$ results, etc. A complexity of these goods' essence makes the customers (investors) to use the engineering services (particularly, consulting engineering) during making a decision about purchasing one or another product. A demand for this kind of services is now increasing all over the world. But the processes of engineering services markets' development in the world countries go differently [4].
In spite of the said, some general problems exist in the field of consulting engineering and other engineering services. In particular, it's a problem of choosing an acceptable management model. A reason for the situation is a low number of the investigation in the field of determining the economic essence of the engineering services, organizational features of the interactions between consulting firms and customers, evaluation of the knowledge products [5], [6].

One of the significant ways to solve these problems may be paved by investigating an institutional essence of the engineering services, engineering companies' and customers' strategy. Then the results of the investigation, coupled with the evolutionary economy methodology, should be used to work out the evaluation instruments for the innovation projects and $R \& D$ results.

\section{Institutional essence of the engineering services}

Making a decision about acquiring of any good makes necessary a measuring (evaluation) of its characteristic. This measurement requires incurring some costs.

The types of costs that exist during the transactions' profitability analysis or other measurements are defined as measurement costs. The cost for activities, which's goal is to indemnify the participant from losses caused by the measurement errors should also be defined as the measurement costs.

"Measurement costs" as a term first was used by Y. Barzel in his well-known work [7]. But he wasn't a first one who showed the importance of problems that

Corresponding author: kolbachev@yandex.ru 
exist during the measurement processes. In the work [8] by M. Yudkevich it's pointed out that the first one who presented a concept of minimizing the information scattering by market organization was S. Cheung [9]. This concept is a basis for measurement costs' valuation.

In context of the situations we examine, the important role play institutions that decrease a measurement costs' level. The first consideration of this problem was presented in the above mentioned work [7] by Y. Barzel. These institutions also generate the negative incentives that prevent an existence of the adverse selection and opportunistic behavior. Thereby they decrease the negative consequences of the informational asymmetry. It's obvious that the engineering as an institution should be attributed to this kind of institutions.

According to the ideas of institutional theory, engineering may be represented as a transaction institution for the knowledge mediation. It's to be considered as a particular case of the transaction institution, a consulting service, that works as a mechanism of decreasing a measurement costs level [10]. Speaking about measurement costs we have to take in account that the existence of information search costs and measuring of the respective contract attributes should be considered as a factor that hampers the processes of decreasing the informational asymmetry level.

The result of incurring the measurement costs is a partial (not final) decreasing of the price and quantitative ambiguity [11].

According to J. Hirshleifer [12], the existence of a quantitative ambiguity is much more serious problem than price ambiguity. A reason for this assertion is a multidimensionality of the good's or service's qualitative characteristics. The problem is that some aspects of these characteristics may be immeasurable, and in the existence of the subjective appraisal in measuring some good's or service's attributes.

Valuation of the credence qualities often becomes a part of engineering services, because this valuation can't be done by the customer, as opposed to the search or experience qualities. The credence qualities are the ones, which's valuation is a reason for incurring costs, even after the concluding of a contract. Valuation of the credence qualities as a part of engineering services may be hold in combination with the diagnostics. They should be hold before making a final decision about concluding a contract for carrying out a project and may be a reason for essential increasing of the costs level, especially if the customer negotiates with more than one vendor. The above said should be understood as an example of rather often existing situation when the engineering company fills the consuming or the investing company's order to choose one of the forms of the invention for the future acquisition and use.

In this situation the engineering services act as the means of averting both the customer's and the vendor's (or the developer's) opportunistic behavior.

According to the ideas of M. Yudkevich [8], in this situation the customer has a deal with "two markets in the same time": market for goods and services and information market. Rather often the same agent presents the both offers (goods and information) in the both markets. As an example, the engineering company often presents the information about existing inventions and the possible ways of their development by the phase of practical use, and in the same time, makes a design work for this development. The existing situation promotes the opportunistic behavior of engineering company that can be revealed as a part of the engineering company's strategy.

\section{Strategies of the engineering companies and their customers}

To analyze the possible strategies of the engineering companies and their customers we have to bring the engineering services and the goods that we are going to valuate into the correlation with one of the categories.

In nowadays economy exists a well-known goods and services classification based on ideas by P. Nelson [13], M. R. Darby and E. Karni [14]. P. Nelson marks out two basic groups of the goods: search goods and experience goods, and shows the difference of these groups' quality definition. Search goods' valuation and measurement of their quality should be done before the entering into a contract. Valuation and measurement of the experience goods' quality is being done during their use or exploitation. It's obvious that innovation projects, R\&D results and other kinds of knowledge products should be classified as search goods.

Information about the quality level of these products is very important for the potential consumer. Information about quality level may be obtained the same way as about price level. But sometimes obtaining of this information causes so high-level expenses, so the customers look for another ways of getting it.

There are some categories of goods, which's quality can't be determined by the customer himself. The reasons for such situation are the technical complexity of the goods, or some others. In this situation the quality level should be determined by the outside economic agents. Engineering companies' work on project valuation is a kind of outside agents' work. So, the problem of the economic agents' (as of the developers' and intermediates') trustworthiness becomes actual for the consumer who uses their information for the decision-making.

To solve the problem, M. R. Darby and E. Karni [14] suggest to measure the good's general quality level not only by search and experience quality parameters, but use another one, the credence qualities. Valuation of the credence quality level can't be done by the customer and should be handed over to another economic agent.

Under the said conditions, according to the opinion of M. Yudkevich [8], the engineering company as an intermediary may implement one of the following possible strategies:

- "Cooperate" - to "play fairly" in a period of rendering the intermediary services to the customer, without being in collusion with the vendor and taking all measurements 
to determine the only optimum alternative for the customer's contract;

- "Deviate" - to violate the conditions of the contract with the customer being in collusion with the vendor, or choose goods for the customer basing on an insufficient number of the measurements.

In the same time the customer may implement one of the next two strategies:

- "Stay" — to extend a period of using the intermediary's services;

- "Refuse" — to reject the presented intermediary's services and take a project quality measurements using the own abilities, or use other intermediary's services.

In our reasoning we proceed from the fact that the customer follows a trigger strategy. It means that if the intermediate followed a "Cooperate" strategy in a previous term, then in a current term customer follows a "Stay" strategy and uses this intermediary's services. If the intermediary violated the conditions of the contract in a previous term and followed a "Deviate" strategy, then in a current term and in all further periods customer should follow a "Refuse" strategy. But in the first period the example intermediate follows a "Cooperate" strategy. It's obvious that the thoughtless following this strategy is an impermissible simplification of the situation. In the actual conditions a great number of various factors affect the customers' and the intermediates' behaviour.

Using of the high-grade instruments for evaluation of the inventions makes the opportunistic behaviour (both the developers' and the engineering companies') less possible. These instruments should give a possibility to quantify the qualitative characteristics of one or another invention. During this work the most important becomes an integrated assessment that gives a possibility to compare the inventions with the differing particular parameters. A possible way of such assessment is attributing the invention to one of the technological structures.

In this situation using a natural science or technical science methodology is necessary for solving a management problem of choosing the optimal technological option, methods and instruments.

\section{Instruments of the evolutionary economics used for the evaluation of innovation projects and $R \& D$ results}

During the evaluation of the innovation projects' and R\&D results' credence qualities, using the cost parameters looks very difficult because of evaluation's limited possibilities. Another problem is the affecting of the numerous factors that are not in a close proximity with the basic characteristics of the evaluated object, such as the inflation rate, economic situation, etc. It's remarkable that these kinds of cost evaluation method's shortcomings are described in the well-known works by such scientific authorities as M. Friedman [15], L. I. Abalkin [16], G. Odum [17] et al.

Russian academician L. I. Abalkin [16] noted that dissatisfaction with economic science's condition was the first sign of the old paradigm exhaustion and the necessity in a new one. At the first step of its creation the system of analogies can be used - an application of methods of the other sciences such as biology, genetics and thermodynamics that are widely used for the analysis of economic processes' cyclical dynamic.

It seems to be noteworthy the position of M. Friedman [15] suggesting that economic theory can be exact and objective as much as natural sciences. The problems of objectivity and reliability of measurements and estimates in economy were figuratively described by A. Hall [18] who mentioned that a great blemish of the market prices system was the instability of money unit, “... a physicist wouldn't bear a yard-stick made of rubber..."

G. Odum [17] considers a range of logically interconnected problems determining relations between energy, ecology and economic growth. He proves that economic processes exploring only through money circulation is as incomplete as natural phenomena exploring only through mineral cycles. This approach, which is rather constructive, has an essential disadvantage connected with neglecting an entrepreneurial (intellectual) aspect in formation of engineering, organizational and management decisions that define the character of resources transformation into production factors and provide the effectiveness and efficiency of production and other processes in social-economic and technical-economic systems.

It's obvious that carrying out of the engineering services requires the estimation of the invention's technical and economic level. To do this, it's necessary to find a continuum between its technical parameters and parameters of its economic type (but not only the cost parameters).

To solve the said problem it's appropriate to use the evolutionary economics methodology. This methodology was worked out in the postshumpeterian period of development of the economic science in the well-known researches of such scientists as J. Foster [19], R. Langlois [20] and C. Shubert [21], V. Mayevskiy [22], O. Sukharev [23] at al.

One of the actual lines of nowadays evolutionary economics development is a theory of technological structures (technological orders), devised in the works by S. Glaziev [24], C. Perez [25] and some other authors.

During the integrated assessment of the inventions' credence qualities, which should be hold as one of engineering services, attributing the invention to one of the technological structures is an available way. The procedure of such attribution is described below.

This method is a particular case of a successful using a natural science methodology for the engineering problem solving as the prime transaction institution of knowledge intermediation.

The quantitative characteristics of the technological structure is the materialization level of the production systems' information, which level 
increases as far as the previous order is changed by the subsequent. The original approach to this idea is shown by O.M. Yun [26], who examined the technological relations and functions, implemented by the production system (q.v. Tab. I). This approach should be used if we have to analyze the changing informational relations under the different technological structures.

During their evolution, the informational content of the labor processes in the production systems changes greatly. The nature of the proper information medium, which determines the general appearance of the production system of one or another technological structure, also changes. Basing on this statement and the materials by I. Pereyaslova [27], we present Tab. II, in which the informational processes are shown. These processes are being materialized, respectively, on the instrumental, machine and informational steps of the production development.

Another quantitative characteristic of the technological structure is the forming processes' dimension scale. The forming processes should be analyzed for the dominating technology, which technology determines the economic result of the production (q.v. Tab. II).

The dimension scale value decreases as far as the previous structure is changed by the subsequent. From the first to the forth structure the reason for this regularity was based on the increasing of the mechanical engineering products' dimensional accuracy: the dimensional accuracy determined product's performance. The fifth structure appearance is associated with the development of the micro system electronics, which operates the dimensional parameters accuracy within micrometres.

Examining how much the information materialization level and the dimensional scale of the forming processes change, we follow the conceptual proposition that any point on the economic development trajectory is determined by the previous evolution of the production systems in general (I. Pereyaslova [27]).
Table 1. Technological Relations and the Production Functions.

\begin{tabular}{|c|c|c|}
\hline $\begin{array}{l}\text { Technological } \\
\text { relations type }\end{array}$ & $\begin{array}{l}\text { Function } \\
\text { number }\end{array}$ & Function name \\
\hline \multirow{3}{*}{ Pragmatic } & 1 & $\begin{array}{l}\text { Goal-setting, choosing the } \\
\text { product to manufacture }\end{array}$ \\
\hline & 2 & $\begin{array}{l}\text { Grounding the product } \\
\text { characteristics }\end{array}$ \\
\hline & 3 & $\begin{array}{l}\text { Developing the action } \\
\text { program for the industrial } \\
\text { engineering }\end{array}$ \\
\hline \multirow{3}{*}{ Syntactic } & 4 & $\begin{array}{c}\text { Choosing the possible } \\
\text { technologies }\end{array}$ \\
\hline & 5 & $\begin{array}{l}\text { Choosing the technological } \\
\text { relations }\end{array}$ \\
\hline & 6 & $\begin{array}{c}\text { Grounding the production } \\
\text { relations system }\end{array}$ \\
\hline \multirow{3}{*}{ Semantic } & 7 & $\begin{array}{l}\text { Developing the technological } \\
\text { processes system }\end{array}$ \\
\hline & 8 & $\begin{array}{c}\text { Fine-tuning of the } \\
\text { technological processes }\end{array}$ \\
\hline & 9 & $\begin{array}{l}\text { Combination of the manual } \\
\text { labor and machinery work }\end{array}$ \\
\hline \multirow{3}{*}{$\begin{array}{l}\text { Cognitive and } \\
\text { Emotional }\end{array}$} & 10 & $\begin{array}{l}\text { Developing the system of the } \\
\text { instrumental regulators }\end{array}$ \\
\hline & 11 & $\begin{array}{c}\text { Means of the instrumental } \\
\text { operations' regulating }\end{array}$ \\
\hline & 12 & $\begin{array}{l}\text { Regulating of the } \\
\text { instrumental process }\end{array}$ \\
\hline \multirow{3}{*}{ Material } & 13 & $\begin{array}{l}\text { Investment goods } \\
\text { reproduction }\end{array}$ \\
\hline & 14 & Product reproduction \\
\hline & 15 & $\begin{array}{c}\text { Instrumental operating a } \\
\text { subject of labor }\end{array}$ \\
\hline
\end{tabular}

It's obvious that the sixths technological structure should appear with the next decreasing of the forming processes' dimension scale. This statement corresponds to the result of the actual studies of the natural systems and leaving organisms, and processes in these systems, based on the interaction of the molecular and atomic size objects (size from $0.1 \mathrm{~nm}$ to $100 \mathrm{~nm}$ ).

Table 2. Basic Characteristics of the Technological Structures.

\begin{tabular}{|c|c|c|c|c|c|}
\hline \multirow[b]{2}{*}{$\begin{array}{c}\text { Technological } \\
\text { structure }\end{array}$} & \multicolumn{5}{|c|}{ Characteristics of the technological structure } \\
\hline & $\begin{array}{l}\text { Prodution } \\
\text { development } \\
\text { step }\end{array}$ & $\begin{array}{l}\text { Basic economic } \\
\text { resource }\end{array}$ & $\begin{array}{c}\text { Dominant management } \\
\text { concept }\end{array}$ & $\begin{array}{c}\text { Level of the infor- } \\
\text { mation's materiali- } \\
\text { zation }\end{array}$ & $\begin{array}{c}\text { Dimension scale of } \\
\text { the forming } \\
\text { processes }\end{array}$ \\
\hline 1 & 2 & 3 & 4 & 5 & 6 \\
\hline 1 & Instru-mental & $\begin{array}{c}\text { Materi-als } \\
\text { (natural stuff) }\end{array}$ & $\begin{array}{l}\text { Basic production } \\
\text { management }\end{array}$ & $15-11$ & $1-0.2 \mathrm{~mm}$ \\
\hline 2 & \multirow{4}{*}{ Machi-ne } & \multirow{4}{*}{ Energy } & & \multirow{2}{*}{$11-10$} & $100-50 \mu \mathrm{m}$ \\
\hline 3 & & & Production management & & \multirow[b]{2}{*}{$50-10 \mu \mathrm{m}$} \\
\hline \multirow{2}{*}{4} & & & $\begin{array}{c}\text { Management of the } \\
\text { enterprise }\end{array}$ & 9 & \\
\hline & & & \multirow[t]{2}{*}{ Business management } & \multirow[b]{2}{*}{$8-6$} & \multirow{3}{*}{$10-0.5 \mu \mathrm{m}$} \\
\hline 5 & \multirow{3}{*}{ Infor-matio-nal } & \multirow{3}{*}{ Infor-mation } & & & \\
\hline & & & Cost management & \multirow[b]{2}{*}{$5-2$} & \\
\hline 6 & & & $\begin{array}{c}\text { Managing the } \\
\text { technological efficiency }\end{array}$ & & $100-0.1 \mathrm{~nm}$ \\
\hline
\end{tabular}


A transfer of the forming processes to the nanometer level, which takes place within the sixths technological structure, leads to the conceptual changing of the economic instruments that are used for managing the production systems in general and, specifically, for the engineering services. It looks important that this situation makes possible a practical realization of the extremely efficient technology concept. This concept was worked out in the $1980^{\text {th }}$ by Ju. A. Kalyagin [28], and considerably developed at the present time by I. Pereyaslova [29]. Using this concept, we represent the technology, which assures a maximum possible base product yield (100\% selectivity of the process) as the extremely efficient. The level of the real technology's compliance with the extremely efficient (the increasing of this level, first of all, makes the production cost per unit less) can play the role of the efficiency index for the production process.

To make the most out a said methodology to solve the nowadays problems we use the expert appraisal to attribute a project to one or another technological structure. The used measurands are:

- $x_{1}$ - level of the real technology's compliance with the extremely efficient;

- $x_{2}$ - information materialization level;

- $x_{3}$ - dimension scale of the forming processes.

Limits of the parameters variation: $[0,1]$.

Level of the real technology's compliance with the extremely efficient is being measured in the following way: $x_{1}=0$, if the technology level's deviation from the extremely efficient is more then $50 \% ; x_{1}=1$, if the technology level complies the extremely efficient; $\in(0,1)$ in other situations.

Information materialization level is being measured in the following way: $x_{2}=0$, if the materialization level is $>5 ; x_{2}=1$, if the materialization level is $=2 ; \in(0,1)$ in other situations.

Dimension scale of the forming processes is being measured in the following way: $x_{3}=0$, if the scale of the forming processes is $>100 \mathrm{~nm} ; x_{3}=1$, if the scale of the forming processes is $\leq 0.1 \mathrm{~nm} ; \in(0,1)$ in other situations.

Level of the experts' opinions consistency is to be determined as a result of variance analyzing of the indexes they rate. A variation coefficient is to be measured as $i=1,2,3$. If the variation coefficient is less then $30 \%$ for any index, it becomes possible to estimate an integral index.

The integral index of the project's attribution to the modern technological structure is to be estimated using the Euclidean metric method, according to the weight coefficients:

$$
T S=\sqrt{\sum_{i=1}^{3} \alpha_{i}\left(1-x_{i}\right)^{2}}
$$

$\alpha_{i}$ here are the weight coefficients for the factors that satisfy condition. $\sum_{i=1}^{3} \alpha_{i}=1$ (on the current step of work we determine all the parameters as the equal ranking ones).
In present time we work on the economic and mathematical model of for the direct valuation of the project's attribution to one or another technological structure. It is to be based on indexes of technology's compliance with the extremely efficient (using certain parameters from the stoichiometry and chemical kinetics), information materialization level and dimension scale of the forming processes.

\section{Conclusion}

The objective of the presented research is determining the economic (institutional) essence of the engineering services, engineering companies' and customers' strategies. Another objective is working out the instruments for the valuation of the innovation projects and $R \& D$ results, based on the evolutionary economy methodology.

By the result of research we identified the consulting engineering services as a type of knowledge mediation institution. This institution decreases a possibility of the participants' opportunistic behaviour during the purchase and sale deal making. The said is actual first of all for the knowledge products, such as innovation projects and $\mathrm{R} \& \mathrm{D}$ results. The important part of such transaction should be a valuation of the good's search, experience and credence qualities. As a rule, valuation of these qualities can't be done by the customer (investor) himself and should be handed over to another economic agent (mostly often this agent is an engineering company).

During the interaction between the customer (investor) and engineering company, rendering the intermediary services to the customer should be done on terms of the "fair play", without company's being in collusion with the vendor and taking all measurements to determine the only optimum alternative for the customer's contract.

In the article we present a set of measurement instruments to make a said kind of valuation. Concept of the set is based on one of the evolutionary economics' methodologies: a technological structure method. As a criteria for attributing a project to one or another technological structure are used a level of the real technology's compliance with the extremely efficient, information materialization level, dimension scale of the forming processes and dominant management concept.

A presented approach is giving a possibility to decrease a possibility of the opportunistic behavior and, in other hand, to increase the efficiency of the innovation activities.

It's proved that the ultimate products of the sixths technological structure appear during the implementing of the innovations, which's dimension scale of the forming processes is from $0.1 \mathrm{~nm}$ to $100 \mathrm{~nm}$ and their information materialization goes in the levels 5-2 (according to the theory by O. Yun).

The results we got show that using of institutional and evolutionary economy methods to manage the engineering services are reasonable and efficient. 


\section{References}

1. D. North, B. Goutard, Economic Insight, (2014)

2. The Reindustrialization of the United States. Special Report no. 1187 (Euler Hermes Economic Research Department, Paris, 2013)

3. M. Delyagin, Russia for the Russians (EKSMO, Moscow, 2009)

4. K. Fernandez-Stark, P. Bamber, G. Gereffi, Engineering Services in the Americas (Duke University, Durham, 2010)

5. D. Ju. Zavadskiy, Fundamental Researches, 7, (2015)

6. Engineering Services Trade: the Case of South Africa. Sixth Services Experts Meeting-Domestic Regulation and Trade in Professional Services (OECD-World Bank, Paris, 2006)

7. Y. Barzel, Journal of Law and Economics, 25(1), 27-48 (1982)

8. M.M. Yudkevich, Economic Journal of the Higher School of Economy, 3, 358-378 (1998)

9. S. Cheung, Journal of Law and Economics, 53, 53-71 (1974)

10. T. Eggertson, Economic Behavior and Institutions (Cambridge, University Press, 1990)

11. G.J. Stigler, Journal of Political Economy, 69, 213-225 (1961)

12. J. Hirshleifer, American Economic Review, 63, 31-39 (1973)

13. P. Nelson, Journal of Political Economy, 2(78), 311-329 (1970)

14. M.R. Darby, E. Karni, Economica, 12, 67-88 (1973)

15. M. Friedman, American Economic Review, 58, 1, 1-17 (1968)

16. L.I. Abalkin, Issues of the Economics, 5, 4-20 (1994)
17. G.T. Odum, Environment, Power and Society (New York, 1971)

18. A. Hall, Methodology for System Engineering (D. van Nostrand Company, 1962)

19. J. Foster, Biology and Economics, The Elgar Companion to Institutional and Evolutionary Economics (Aldershot, Edward Elgar, 1994)

20. R. Langlois, What is Evolutionary Economics? Evolutionary and Neo-Schumpeterian Approach to Economics (Kluwer Acad. Publ., Boston, 1993)

21. C. Shubert, Darvinism in economics and the evolutionary theory of policy-making (Jena, Max Plank Institute of Economics, 2009)

22. V.I. Mayevskyi, Belorussian Journal of the Economy, 4, (2000)

23. O.S. Sukharev, Evolutionary Economics (Finansy i Statistika, Moscow, 2012)

24. S.Ju. Glaziev, International Economy, 5, 5-27 (2010)

25. C. Perez, Technological Revolutions and Financial Capital (Cambridge: Cambridge University, 2002)

26. O.M. Yun, Production and logics: The informational basis of the development (Noviy vek, Moscow, 2001)

27. I.G. Pereyaslova, E.B. Kolbachev, The Issues of South-Russian State Technical University (NPI), 5, 50-55 (2012)

28. Ju.A. Kalyagin, E.B. Tsyrkin, Using the mathematical methods and computer technologies for design and development of the processes for the petrochemistry, 167-172 (1982)

29. I.G. Pereyaslova, V.V. Shmatkov, The Issues of South-Russian State Technical University (NPI), 4, 6-11 (2013) 